Special Issue 特集論文

Invited Peer-Reviewed Article 招待査読論文

\section{Distribution Functions and Mobile Apps:}

Exploratory Surveys of Mobile Consumer Behaviors

\section{流通機能とモバイルアプリ \\ 一 探索的な消費者調査 一}

\section{亜細西大学 経営学部 准教授 \\ 西原 彰宏}

法政大学 経営学部 教授

新倉 貴士

\footnotetext{
${ }^{*}$ Associate Professor, Faculty of Business Administration, Asia University, Japan, nakihiro@asia-u.ac.jp

${ }^{* 2}$ Professor, Faculty of Business Administration, Hosei University, Japan, niikura@hosei.ac.jp
}

\begin{abstract}
Deconstruction of distribution functions is progressing due to digital transformation. In response, various distribution business models are being developed by retailers. Based on these business models, consumers are provided with mobile apps that combine various retail functions. A focus on the comprehensiveness of the product categories offered to consumers and the integration of retail functions offered enables competitive typology of various mobile apps. For targeting of the mass market, there are leader-type mobile apps that maintain a high degree of comprehensiveness of product categories and highly integrated functions. Conversely, when targeting individual markets, market-specific mobile apps and function-specific mobile apps are found at the opposite ends of these axes. In this paper, we investigated the actual usage of mobile apps and the perceptions of these apps for smart shopping and shopping enjoyment, while keeping in mind the competitive typology of various mobile apps that reflect each distribution business model.
\end{abstract}

Keyword : Loyalty, Business model, Smart shopping, Shopping enjoyment

要約 : デジタル变革により流通機能の脱構築が進行している。これを受けた小売現場では, 多様な流通ビジネスモデルが展開さ れている。こうしたビジネスモデルを背後に，消費者には様々な機能を兼ね備えたモバイルアプリが提供されている。消費者に 提供される製品力テゴリ一の総合性と提供される機能の統合性を軸にすると, 多様なモバイルアプリの競争的な類型化が可能に なる。マス・マーケットを対象とすると, 製品カテゴリーの総合性と機能の統合性を高く保持するリーダ一型のモバイルアプリ の存在が見いだせる。逆に個のマーケットを対象とすると, それらの軸の逆方向に, 市場特化型のモバイルアプリと機能特化型 のモバイルアプリが見いだせる。本稿では, それぞれの流通ビジネスモデルを反映するモバイルアプリの競争類型を念頭にお き, モバイルアプリに期待される買物のスマートさと買物の楽しさを中心にモバイルアプリの利用実態とその認識に関する調査 結果を報告する。

キーワード : ロイヤルティ, ビジネスモデル, 買物のスマートさ, 買物の楽しさ

Information : Received 1 June 2021; Accepted 15 June 2021

\section{I. はじめに}

急速に進行するデジタル変革を結果的にコロナ禍が後 押しする形となった現在, 今一度, マーケティングの基 本に立ち戻って考えてみたい。特にビジネスのあり方と
消費者目線という視点についてである。これらは, これ までに幾度も繰り返し強調されてきたが，やはりマーケ ティングの基本を考えるうえでは強調すべきものであ ろう。

本稿では, ビジネスのあり方という視点については, マーケティングにおけるデジタル変革のなかで劇的な勢 
いで進展している流通の領域に着目し，流通機能と流通 ビジネスモデルの動態性について考察する。そして，消 費者目線という視点については，現在の消費生活におけ るデジタル变革の中心的役割を担っているモバイルアプ リに焦点をあて，その利用実態を把握するなかで，消費 者のモバイルアプリに対する認識を考察する。様々な流 通機能の統合体であるモバイルアプリを消費者はどのよ うに認識しているのだろうか。

以下ではまず，流通のはたす機能を再考しながら，デ ジタル変革によって進行する流通機能の再編を理解す る。次に，小売業に焦点をあて，そのビジネスのあり方 について提供機能と対象市場という 2 つ観点から整理 する。そして，小売業者が提供するモバイルアプリにつ いて，その裏側で展開される流通ビジネスモデルの現状 を把握するとともに，その表側で展開されるモバイルア プリの競争類型を試みる。さらに，これらの現状分析を 踏まえて行った探索的な消費者調查の結果について報告 する。

\section{II. 流通機能の再考}

\section{1. 流通機能のアンバンドリング}

マーケティングにおける流通研究では，流通機能とし て商流（所有権）機能，物流機能，情報流（情報伝達） 機能，資金流（危険負担）機能という4つの機能が識別 され（Tamura, 2001），生産を担う製造業者と消費を行う 消費者の間に介在する流通業者には，これらの機能を十 分にはたすことが期待される。こうした流通機能に着目 すると，現在のデジタル変革を受けた小売現場での様々 な現象は，これまで比較的安定性を保ってきた流通機能 の束が解体されるという流通機能の「アンバンドリング」 （Yahagi, 2016）として理解できる。

このアンバンドリングは，大きく 3 つの現象を引き起 こす（Niikura, 2015a）。流通機能ミックスの変化，流通 フロー参加者の交代，流通チャネル構造の変化である。 流通機能ミックスの変化とは，アンバンドリングによっ て解体された機能の束を再構築するべく, 機能ミックス においてミックス要素の比重を変えることで，既存の流
通業者を新たな姿に生まれ変わらせる。具体的には, 品 揃えの徹底追求や独自の流通経路開拓といった商流機能 や物流機能を強化したり，徹底した店頭サービスを行う といった情報流機能の強調もよくみられる。

流通フロー参加者の交代とは，アンバンドリングによ り, 4 つの個別機能のフロー要素における遂行能力の強 さを背景に登場する，従来では想定しえなかった既存の 流通業者以外の参加者にとって代わることである。現在 では特に, デジタル変革の推進役として「情報フロー」 において卓越した遂行能力をもつプレーヤーの参加が際 立っている。

最後のチャネル構造の変化とは, これまで流通機能を 遂行してきた流通業者以外の製造業者や消費者が，プ レーヤーとして流通機能を担うという形で現れるもので ある。流通機能はなにも流通業者の特権ではなく, 誰が その機能をはたしても構わない。一般に, これらの機能 を遂行する能力が高い者たちが流通業者となり，その役 割を演じているに過ぎない。しかし, 機能ミックスの変 化を感じ取り，流通フロー参加者の交代を目の当たりに すると，製造業者や消費者までもが流通機能を代替する ようになる。製造業者や消費者がチャネルリーダーとな り, 従来のチャネル構造に大きな変革を及ぼす。しかも, デジタル変革により, この交代は従来よりもいっそう容 易になりつつある。

\section{2. 小売業の提供機能と対象市場}

ここではモバイルアプリを念頭に㧍き，流通機能のう ち小売段階での機能に着目しながら，小売業のあり方を 考える上で重要となる小売業の本質を押さえる。 Shimaguchi（1986）は，その本質を「消費者の購買代理 機能にある」と捉え, 消費者ニーズの類型化に基づく小 売形態を論じる中で, 以下の 4 つの小売業態を識別して いる ${ }^{1)}$ 。

（1）経済機能追求型小売業とは，価格訴求を狙い，七 ルフサービス方式による大量販売を志向する業態である。 ここでは, 徹底的な合理化, 標準化, システム化を志向 した管理スキルの効率性が原動力となる。「マス・マー ケット」を対象として，標準化を中心に「売れるものを さらに徹底して安く売ること」に注力する。したがって, 
「売れ筋のよいものをどのように効率的に絞るかという マーチャンダイジング・スキル」が要求される。

（2）人間中心型小売業とは，価格以外の価値が重視さ れ，専門情報の提供や人間的接触などを志向する業態で ある。（1）に比べると，「「マス・マーケット」より「個 のマーケット」を狙い，標準化，システム化でなく，む しろ，その落ちこぼれた部分に，ヒューマンな「商人道」 を主体とする柔軟で思いやりのある対応や，豊富で親身 な専門情報の提供，あるいは人間的アメニティ空間や応 待を提示する専門小売業」である。すなわち，個別消費 者へのカスタマイズ機能の対応能力と独自のヒューマン タッチなアメニティ（楽しさ）が要求される。

（3）価值・効率折東型小売業とは，上記 2 つの小売業 態を合わせたものであり，「マス・マーケット」と「個の マーケット」を対象に, 非定型的購買や多目的購買を狙 う業態である。管理スキルを充実させ，全体の統合性と 合理性を追求しながらも，ヒューマンタッチな商人道の 追求が必要とされる。「購買の緊急度がある程度低いた め, 顧客をどれだけ長く店舗にとどめておくかが重要に なる。つまり，店舗内の顧客の滞留化が売り上げ上昇に 結びっくため, その目的にそった店舗内の「空気づくり」, 売り場レイアウトの再編成, 非売り場スペース内でのア トラクションの演出などが成長の競争差別をつくる」と される。

（4）コングロマリット型小売業とは，上記 3 つのう ち, 「経済機能追求型小売業や価值・効率折贵型小売業の 一部がさらに発展した段階でとられる形態」ともいえる 業態である。潜在的な市場を確定させた後に，それに適 合させるように小売業態の選択をしていくという柔軟性 をもち合わせていると考えられている。

上記 4 つの小売業態は, オフラインでの小売業のあり 方を論じたものであるが，オンラインを付加した現在で も，小売業の本質を考えるうえで大いに参考になる。こ こで重要と考えられるのは,「経済機能追求/人間中心」 という提供機能のあり方と「マス／個」という対象市場 の設定の仕方であり，これらにより小売業のあるべき姿 への対応の手立てが大きく異なるという認識が必要に なる。

\section{III. モバイルアプリの進展}

\section{1. モバイルアプリの裏側：多様化する流通ビジネスモ デル}

現在，流通に扔けるデジタル変革を促しているのは, モバイルアプリの急速な発展と浸透であろう。消費者目 線からみたモバイルアプリを検討する前に，モバイルア プリの裏側で展開される流通ビジネスモデルについて理 解しておかなくてはならない。

現在, デジタル変革により流通機能を担う流通業者の ビジネスモデルが多様化している。この多様性を理解す るには, 流通において展開される取引形態を把握しなく てはならない。図1は，流通において大きく二分される 取引形態の違いを示している (Yahagi, 2020)。上段の「パ イプライン型バリューチェーン」は，これまで伝統的に 展開されてきた取引形態である。流通業者である卸売業 者や小売業者が売買の主体となり流通機能をはたすこと で，製造業者から消費者へと垂直的なパイプライン型の 経路が確立される。ここでは, 各機能遂行者が所有権を 移転させながら「売買差益」を獲得していくというビジ ネスモデルが展開される。ここでの取引関係はクローズ ドなものであり，各主体は所有権をもつために在庫など のリスクを抱えなくてはならない。

下段に示されるのは,「プラットフォーム型両面市場」 である。プラットフォームビジネスとは,「ある特定の事 業主がプラットフォームを構築し, プラットフォーム上 で相互依存的な複数の顧客グループを仲介して, 彼らの 直接的な相互作用を通して価值を創造する仕組み」と定 義される。顧客グループが 2 組であると両面市場，さら に顧客グループが加わり 2 組以上になると多面市場とな る。上段のパイプライン型と大きく異なるのは，プラッ トフォーマーは売買の主体ではなく, 売買の仲介を行う ことによる「手数料収入」などを得ることでビジネスモ デルを成り立たせている点である。ここでの取引関係は オープンなものであり, プラットフォーマーは所有権を もたないのでリスクを抱える必要はない。

図 2 は, 上記 2 つの取引形態を識別基準の一つとし, さらにオフラインとオンラインという識別基準によって 
〔パイプライン型バリューチェーン〕

製造業者

卸売業者

小売業者

消費者

売り手・買い手の交互連鎖構造

〔プラットフォーム型両面市場〕

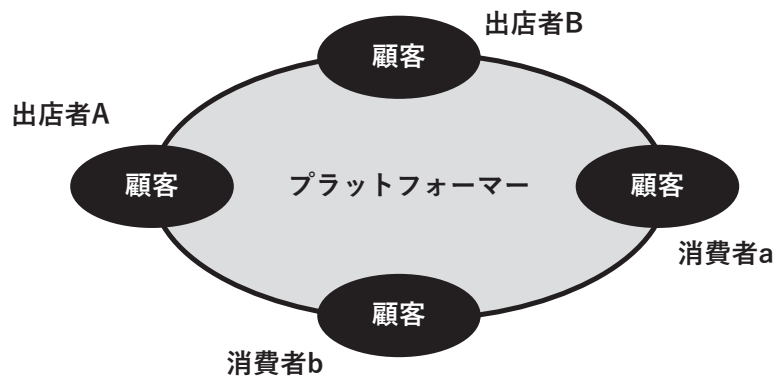

出典 : Yahagi, 2020, p. 71, Figure 1 より修正して引用

分類した流通ビジネスモデルの類型である（Yahagi, 2020）。オフラインの世界で展開されてきた伝統的な流 通ビジネスモデルは, パイプライン型オフライン系の「線 形経路モデル」である。この世界ではまた，テナントを 集めて集客するショッピングモールやショッピングセン ターに代表されるプラットフォーム型オフライン系の「集 積経路モデル」がある。もう一方のオンラインの世界で は，パイプライン型オンライン系の「短縮経路モデル」 が展開されている。ここでは，製造業者，卸売業者，小 売業者の区別なく，インターネットを介して直接的に消 費者との取引が可能になり，オフラインの世界よりもそ の経路が短縮される。またオンラインの世界では, プラッ トフォーム型オンライン系の「仲介経路モデル」もある。 インターネット上で独自のショッピング空間（プラット フォーム）を創造して，その空間で売り手と買い手の自 由なやり取りを可能にさせるものである。

これらに加え, 実店舗に基づくオフライン系と EC（電 子商取引）を駆使するオンライン系を組み合わせて，両 者を融合して展開する「オムニチャネルモデル」も注目 を集めている。

さらに, クローズドな取引関係をもつパイプライン型
とオープンな取引関係をもつプラットフォーム型を融合 した「ハイブリッドモデル」も展開されている。このよ うに現在では, 都合 6 つのビジネスモデルを認識できる が，デジタル技術と競争の展開により，こうしたビジネ スモデルは急速に変貌を遂げるということを理解してお かなくてはなるまい。

\section{2. モバイルアプリの表側：期待される提供機能とその 統合性}

以上のようにモバイルアプリの裏側では，流通ビジネ スモデルをめぐる各社の嬂烈な競争が展開されているが, 消費者目線からは単に，自分にとって適切であり，使い 勝手のよいモバイルアプリを求めているに過ぎない。

消費者に映るモバイルアプリの表側には，消費者の購 買意思決定プロセスを想定すると, 様々な提供機能が期 待される（Niikura, 2015b）。商品やサービスに関しては, 情報探索の段階では商品やサービスの検索機能, 理解す る段階では画像や動画に加えて xR（VR/AR/MR/SR） な ども駆使したイメージ作成機能, 考慮集合や選択集合の 形成段階では忘備録にもなる買物リスト作成機能が期待 されるであろう。またプロモーションに関しては，プッ 


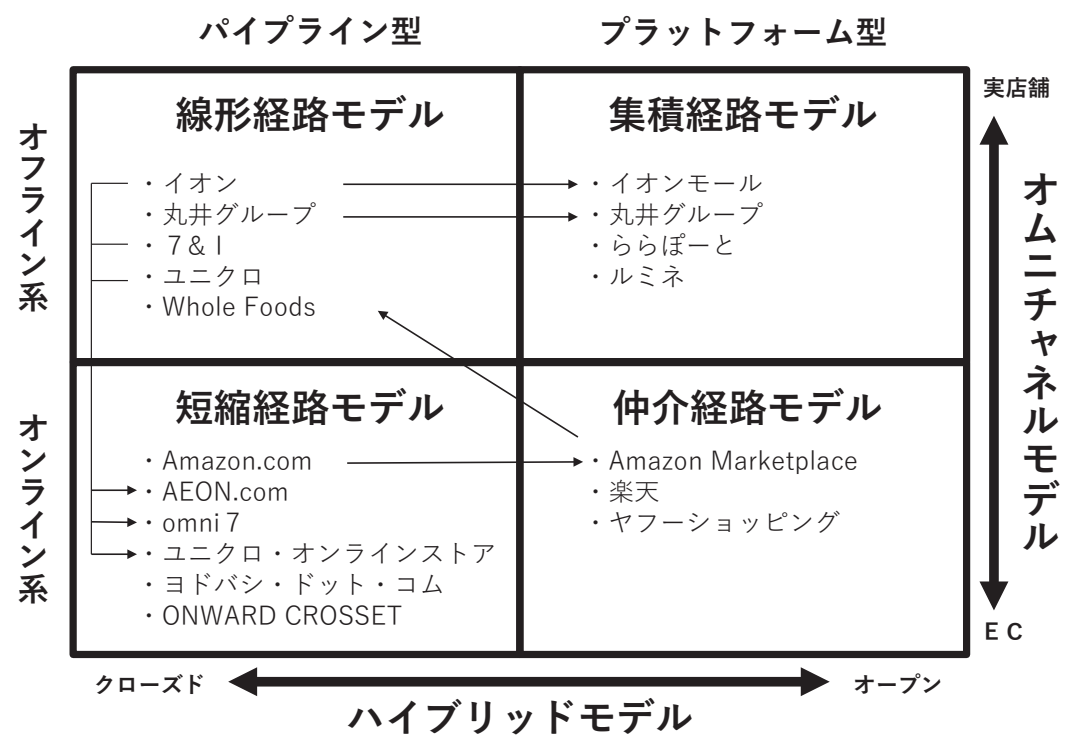

出典：Yahagi, 2020,p. 77, Figure 3 より修正して引用

シュ通知によるニュースやクーポンなどの配信機能，来 店誘導や店内でのナビゲーションの機能などが求められ る。さらに決済に関しては，スマートショッピングをイ メージさせるスキャン＆ゴーなどのセルフスキャン機能 も期待される。そして, 商品の出荷・配送に関するプロ セスや確実な受取が把握できる機能にも期待が寄せら れる。

こうした様々な機能の統合体としてのモバイルアプリ について，消費者は「スマートさ」という使い勝手のよ さを感じるのであろう。また，消費者自身にとって適切 であることには，消費者個人の好みや価值観が大きく反 映される。消費者によって，それぞれお気に入りの店舗 があるように，モバイルアプリにも個人的な感情や価值 観を反映した適切性がある。そして，その適切性にかな うと, 提供される機能のカスタマイズ性や意外性といっ たヒューマンタッチなアメニティを「楽しさ」として感 じるのであろう。これらの点は, Shimaguchi（1986）の 業態類型軸としても検討されていたように，小売業の本 質を考察するうえではきわめて重要なものであり，現在 でも買物価值概念の構成要素として議論され続けている (Huré, Picot-Coupey, \& Ackermann, 2017)。
マーケティングにおいて関係性が強調されるように なってからは, 顧客獲得よりも顧客維持に向けた議論が 色濃くなっている。それを反映して，顧客ロイヤルティ やブランド・ロイヤルティといったロイヤルティ概念の 重要性が指摘されてきた。ここでは, 反復購買（継続購 買）として行動面から捉える立場と, 愛顧となる認知や 態度の側面から捉える立場があることは認識しておく必 要がある。但しロイヤルティ概念は, あくまでも購買に 基づく概念であるので経済的関係に過ぎない。

一方で, コンタクトポイントの重要性が認識され, 購 買と購買以外のすべての接点を抑えながら, そこで生み 出される経験価值の理解が必要となってきた。そこで, 購買以外での接点における行動や心的状態への関心を基 にしたエンゲージメント概念が着目されてきた。エンゲー ジメント概念は, 購買以外で展開されるクチコミや推奨 行動などの積極的な行動や心理状態であるため, 非経済 的関係として理解できる（Nishihara, 2020）。

したがって，モバイルアプリに関する関係性という視 点からは，特定の小売業者に対するロイヤルティやエン ゲージメントと同様に, 消費者が当該モバイルアプリを 気に入り，継続的に使用しながら，社会的にも拡散した 
いという心的傾向と拡散行動として理解できる。

以上のように，モバイルアプリの表側では，提供され る様々な機能に基づいたモバイルアプリ全体について, スマートさと楽しさという観点から要約的に捉えた機能 の統合性が認識されていると考えられる。そして，その 統合性に基づて消費者との適切性が判断され，さらに 利用の継続性や拡散性などが規定されているのであろう。

\section{3. モバイルアプリ間の競争}

現在, 消費者の購買代理機能をはたす様々なモバイル アプリが存在している。図 2 に示されるビジネスモデル を競いながら，消費者の目には，モバイルアプリ間の競 争が映し出されているだろう。 Shimaguchi and Ishii （1987）は，競争者の分析においてそのタイプ分けを論 じている。そして, その際に重要となる 2 つ軸とし て，「製品ラインの広がり」と「機能の統合性」を指摘し ている。前者をもつフルラインの強みには, 製品間のシ ナジー効果, 製品流通面や広告サービス面での規模の経 済性, 流通業者との取引上の優位性がある。後者をもつ 強みとして, 経営諸機能の共同化によるロジスティクス
面での合理化, 市場や技術の変化への即時的対応, 機能 に関する技術習得が可能になることを示している。

図 3 は, モバイルアプリの競争類型を示している。上 記の競争者の夕イプ分けでは，主に製造業者が想定され ているようだが, 小売業者のモバイルアプリにも適用可 能であると考えられる。ここでは消費者に提供する流通 機能を考慮して，小売業者の商品取扱い技術とビジネス モデルの性質を反映した「製品カテゴリーの総合性」と， 消費者への提供機能の多様性を考慮した「機能の統合 性」を用いる。

「製品カテゴリーの総合性」が強みとなるのは, ワンス トップショッピングへの即応力, ロングテールへの対応 力, プロモーションにおける規模の経済性, 取引相手 (製 造業者, テナント, 配送業者など）への取引上の優位性, プラットフォーム型モデルでのネットワーク外部性など が考えられる。例えば，アマゾンでは，オンライン系の 「短縮経路モデル」と「仲介経路モデル」を組み合わせる ことで高い次元の製品カテゴリーの総合性を実現してい る。「機能の統合性」が強みをもつのは, シームレスな利 便性の提供, 重視機能や操作機能の変化への即時的対応,

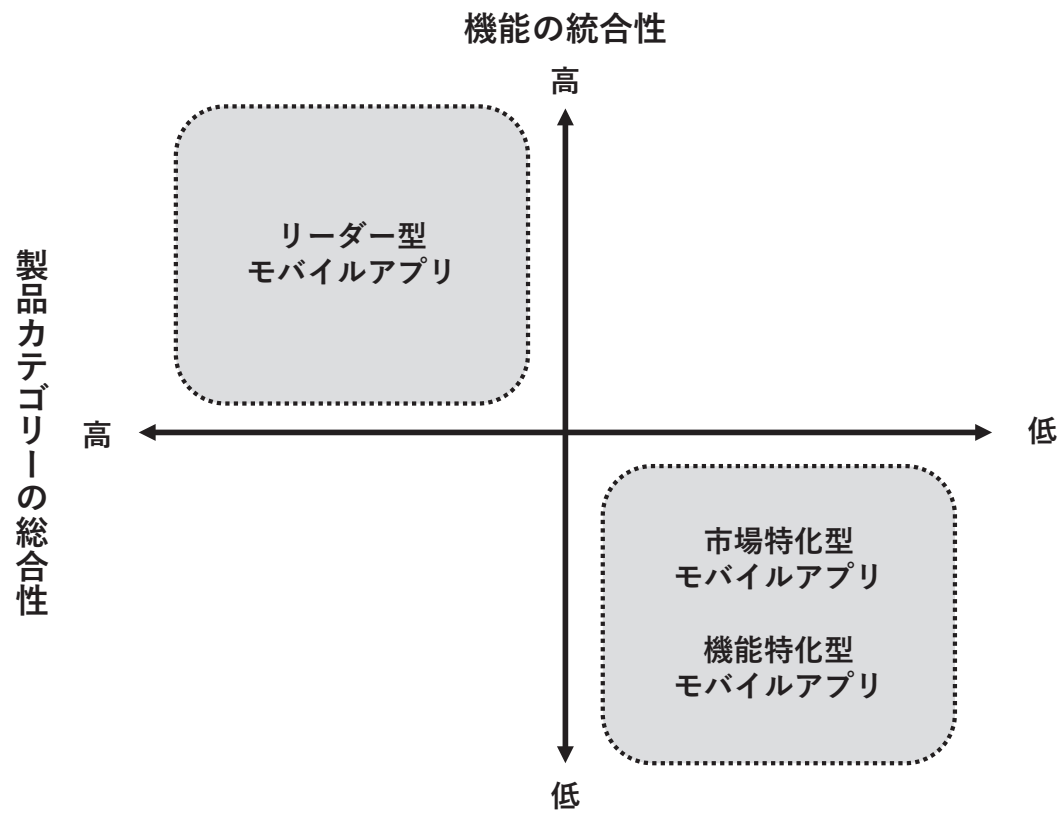

出典 : Shimaguchi and Ishii, 1987, p. 119, Figure 5-3 より修正して引用 
機能に関する技術習得と利用情報の獲得などが可能にな るためである。

小売業者のモバイルアプリは，自らの依拠するビジネ スモデルの特徵と限界を反映した対象市場と提供機能か ら競争的に位置づけられるであろう。オープンな取引形 態をとるプラットフォーム型の方が，取り扱い製品カテ ゴリーの総合性は高くなり，「マス・マーケット」を狙い やすくなる。そして, 対象市場の広さに伴う提供機能の 多様性が要求される結果, 機能の統合性を兼ね備えたリー ダー型のモバイルアプリが図の左上に位置づけられる。 ここでのリーダー型モバイルアプリにおいては, 図 2 に 示される流通ビジネスモデル類型の内，前述したアマゾ ンなどのようにオンライン系の短縮経路モデルと仲介経 路モデルのハイブリッドモデルを志向する形や，実店舗 と $\mathrm{EC}$ などの自社チャネルなどを連携させるオムニチャ ネルモデルを志向する形など複数の形態がある。

逆に, クローズドな取引形態に制約されるパイプライ ン型では, 製品カテゴリーの総合性に限界があるために, 「個のマーケット」に向かう傾向がある ${ }^{2)}$ 。そして, 特定 市場に限定した市場特化型モバイルアプリや特定機能に 重点を置いた機能特化型モバイルアプリが図の右下に位 置づけられる。

\section{IV．消費者によるモバイルアプリ利用に関する探 索的な調查}

本稿では, 図 2 の流通ビジネスモデル間の競争を念頭 におき, 小売業の提供機能に基づいた図 3 のモバイルア プリの競争類型を一つの仮説として，流通のデジタル変 革を推進するモバイルアプリを対象に行った探索的な消 費者調査の結果の一部を報告する。

\section{1. グループ・インタビュー調査の実施}

本稿では，モバイルアプリ ${ }^{3)}$ 関して，利用実態，モ バイルアプリの特徴や機能に対する認識に加え，買物に おけるスマートさや楽しさがロイヤルテイやエンゲージ メントに与える影響について確認することを目的として， グループ・インタビューを実施した。
調査は, 株式会社マーケティング・リサーチ・サービ スが有するモニターを用い, 2020 年 2 月 25 日に都内の インタビュールームで行った。参加者は, 2 グループ (各 6 名）の 12 名である。その際, 日常において頻繁にモバ イルアプリを利用している消費者として，30 代〜40 代 女性, 既婚, 子供を有していること, 有職といった条件 でスクリーニングを行った。インタビューの司会進行は, 客観性の担保という観点から，第三者のモデレーターに 依頼した。

図 2 のビジネスモデルと図 3 の競争類型を考慮した上 で，衣食住全般の商品を扱うアマゾン，楽天市場，ロハ コ ${ }^{4)}$, ファッション・アパレルを扱うショップリスト， ゾゾタウン， ドゥクラッセ，商業施設を展開するパルコ， ルミネの8つのモバイルアプリを対象とした。

スクリーニング条件としては, 上述したいずれかのモ バイルアプリの利用者であり，その際，閲覧頻度が2〜 3 日に 1 回以上, 購買頻度が月に 2,3 回以上, そして, その買物に楽しさを感じていることを条件とした。上述 した 8 つモバイルアプリの内，利用したことがないモ バイルアプリに関しては，事前に操作・閲覧・利用する という課題を事前に課した。

主な質問項目は，モバイルアプリに関して，日頃の利 用状況, EC (ブラウザによる利用含む) の利用状況や買 物実態, 操作感や評価, 利用前後における購買行動の变 化，加えて，モバイルアプリないし EC 事業者に対する ロイヤルティやエンゲージメント 5)などである。

グループ・インタビューの参加者による発言を整理し, 以下の知見が得られた。第一に，モバイルアプリの利用 および利用継続（ロイヤルティ）に関わる重要な要素と しては, (1)モバイルアプリ（EC 事業者）に対する信頼 性（決済は問題なく行えるか, 偽物を掴ませられないか, 商品が間違いなく届けられるかなど), (2)品揃え（希望す る商品があるか, 見つかるかなど), (3)価格の安さ（送料 などを含む)，(4)買物におけるスマートさなどである。買 物における楽しさは, これら 4 つの要素に続く要素であ るが, 他に比べると重要度が低いと思われる。上記は, それぞれの要素間や，後述する他の知見とも関連してい る。さらに, ロイヤルティに対して, 楽天ポイントなど のポイント経済圈や, アマゾンプライム会員などの有料 
会員向けサービスの享受（支払い分の会員費用の回収意 欲）など，複雑な要素が関わっている。

第二に，モバイルアプリの競争類型を識別する軸の 1 つである「製品カテゴリーの総合性」について，消費者 からは, 品揃えの豊富さとして認識されたり，買物にお けるスマートさの要因として捉えられている。例えば, 子供の通う学校の指定や習い事先の指定といった条件付 きの買物時や，店舗では欠品していた商品，複数の製品 カテゴリーに跨る買物時において，品揃えの豊富さによ るワンストップショッピングの観点からモバイルアプリ を活用するという点である。製品カテゴリーの総合性の 高さは, 購買目標や購買課題を完遂しやすいといった利 点に繋がる一方で, 商品選択における時間や労力が必要 となることもあるため，必ずしも買物のスマートさに寄 与するわけではないことが確認された。

第三に，もう1つの軸である「機能の統合性」につい て，大きく 2 つのはたらきが見いだされた。1つ目は， （実店舗を有する場合は）モバイルアプリを通じて，実店 舗などの他のチャネルを跨いだ購買をシームレスにする ような機能である。モバイルアプリは，オムニチャネル におけるシームレスな購買を実現する重要なキーデバイ スとして位置づけられる。2つ目は，モバイルアプリの みで購買が完結できるようにしたり，その買物をスマー トにしたりする機能である。例えば，使用経験や評価に 関するクチコミを投稿および閲覧可能にする機能に加え， 画像や動画などにより購買意思決定を補助する機能や, 商品の配送・配達に関わる情報を可視化する機能がある。 「製品カテゴリーの総合性」と同様に，操作方法や各種機 能の使い方がわからなくなるなど,「機能の統合性」の高 さは，必ずしも買物のスマートさに寄与するわけではな いことが確認された。

第四に，「買物のスマートさ」と「買物の楽しさ」につ いて，その内容を確認できたことである。これらは，第 一の知見に扔けるモバイルアプリの利用および利用継続 （ロイヤルティ）に扔ける重要な要素にもあげられてい る。「買物のスマートさ」については，非常に多義に渡 り，例えば，面面の見やすさ，価格の分かりやすさ（出 品事業者毎の価格，送料やポイント割引を踏まえた価格 など)，情報の見やすさ（構成，デザイン，表現など），
検索のしやすさ，操作のしやすさ，決済のしやすさなど があげられて抢り，さらにそれぞれの下位項目が見いだ される。また，買物の楽しさについては，買物というプ ロセスに打ける楽しさ以外にも，見る楽しさ，買う楽し さ，新たな用途を発見する楽しさなどがある。

\section{2. 質問調査の実施}

消費者によるモバイルアプリの利用実態に加え, 買物 のスマートさや買物の楽しさがロイヤルティに与える影 響を検討するため, Web 上で質問調查を行った。調查 は，株式会社マーケティング・リサーチ・サービスに委 託し， 30 代 40 代の既婚女性を対象に，2020 年 3 月 25 日から 3 月 29 日にかけて実施した。回収されたのは, 1,800 サンプルであった。そのうち，回答に久損のある サンプルや，単調回答，明らかに矛盾した回答に加え， 後述する割り当てられたモバイルアプリを通じた購買経 験の無いサンプルを除外し, 最終的に 1,291 サンプル（全 体の $71.7 \%$, 平均 40 歳, 標準偏差 5.895 歳）を分析に用 いた。

対象としたモバイルアプリは, 図 3 で示した競争類型 を考虑した，衣食住全般に関わる製品カテゴリーを広く 扱うプラットフォーム型ビジネスモデルをもつ国内の 5 つのモバイルアプリである。グループ・インタビューに おいても対象としていたアマゾン，楽天市場，ロハコに 加え, グループ・インタビュー時に被験者間で数多く話 題にあげられていたヤフーショッピング，キューテンで ある。その際，アマゾン，楽天， ヤフーショッピングは 「リーダー型モバイルアプリ」，ロハコは「市場特化型モ バイルアプリ」，そしてキューテンは「機能特化型モバイ ルアプリ」と想定した。割り当ての際, 出現率などの観 点から，前者 3 つのリーダー型アプリを想定したモバイ ルアプリは各 400，他は各 300 となるように配慮した。

被験者は，モバイルアプリ全般䇽よびモバイルアプリ 毎に使用頻度や購買頻度を問う質問への回答が求められ (表 1 参照)，その回答を基に利用経験のあるモバイルア プリが被験者毎に 1 つ割り当てられた。その後, 割り当 てられたモバイルアプリの特徵に関する質問項目への回 答が求められた。このモバイルアプリの特徴に関する質 問は，グループ・インタビューで得られた知見を基に作 
表 1 モバイルアプリ毎の利用頻度と購買頻度の割合

\begin{tabular}{|c|c|c|c|c|c|c|c|c|c|c|}
\hline \multirow[t]{2}{*}{ 割当人数 } & \multicolumn{2}{|c|}{$\begin{array}{c}\text { アマゾン } \\
298\end{array}$} & \multicolumn{2}{|c|}{$\begin{array}{l}\text { 楽天 } \\
297\end{array}$} & \multicolumn{2}{|c|}{$\begin{array}{c}\text { ヤフー } \\
281\end{array}$} & \multicolumn{2}{|c|}{$\begin{array}{c}\text { ロハコ } \\
206\end{array}$} & \multicolumn{2}{|c|}{$\begin{array}{c}\text { キューテン } \\
209\end{array}$} \\
\hline & 使用頻度 & 購買頻度 & 使用頻度 & 購買頻度 & 使用頻度 & 購買頻度 & 使用頻度 & 購買頻度 & 使用頻度 & 購買頻度 \\
\hline ほぼ毎日 & $3.4 \%$ & $.3 \%$ & $15.2 \%$ & $.7 \%$ & $8.2 \%$ & $.4 \%$ & $5.3 \%$ & $1.0 \%$ & $12.0 \%$ & $1.0 \%$ \\
\hline 週に $3 \sim 4$ 回くらい & $6.0 \%$ & $2.0 \%$ & $6.1 \%$ & $.7 \%$ & $3.2 \%$ & $.7 \%$ & $4.4 \%$ & $1.0 \%$ & $5.7 \%$ & $.5 \%$ \\
\hline 週に 2 回くらい & $5.4 \%$ & $1.3 \%$ & $3.7 \%$ & $1.3 \%$ & $5.0 \%$ & $1.4 \%$ & $5.8 \%$ & $2.9 \%$ & $2.4 \%$ & $1.0 \%$ \\
\hline 週 1 回以上（月に 4 回くらい） & $9.4 \%$ & $4.0 \%$ & $6.7 \%$ & $4.0 \%$ & $8.2 \%$ & $2.8 \%$ & $10.7 \%$ & $4.9 \%$ & $13.4 \%$ & $6.7 \%$ \\
\hline 月に 1 ～ 3 回くらい & $28.9 \%$ & $28.5 \%$ & $19.9 \%$ & $25.6 \%$ & $26.3 \%$ & $26.7 \%$ & $28.2 \%$ & $26.2 \%$ & $20.6 \%$ & $22.5 \%$ \\
\hline $2 \sim 3$ ヶ月に 1 回くらい & $20.1 \%$ & $29.2 \%$ & $23.2 \%$ & $30.0 \%$ & $17.4 \%$ & $24.9 \%$ & $15.0 \%$ & $21.4 \%$ & $17.2 \%$ & $23.9 \%$ \\
\hline 4 〜 5月に 1 回くらい & $4.4 \%$ & $6.4 \%$ & $3.7 \%$ & $6.1 \%$ & $5.0 \%$ & $10.7 \%$ & $4.4 \%$ & $8.7 \%$ & $5.3 \%$ & $9.6 \%$ \\
\hline 半年に 1 回くらい & $10.1 \%$ & $11.7 \%$ & $6.4 \%$ & $10.8 \%$ & $11.7 \%$ & $12.5 \%$ & $8.3 \%$ & $8.7 \%$ & $6.7 \%$ & $11.5 \%$ \\
\hline 年に 1 回くらい & $3.0 \%$ & $5.7 \%$ & $3.4 \%$ & $3.7 \%$ & $5.0 \%$ & $7.1 \%$ & $7.8 \%$ & $8.7 \%$ & $6.2 \%$ & $8.1 \%$ \\
\hline 年に 1 回未満 & $9.4 \%$ & $10.7 \%$ & $11.8 \%$ & $17.2 \%$ & $10.0 \%$ & $12.8 \%$ & $10.2 \%$ & $16.5 \%$ & $10.5 \%$ & $15.3 \%$ \\
\hline
\end{tabular}

\begin{tabular}{|c|c|c|c|c|c|c|c|c|c|c|}
\hline & \multicolumn{2}{|c|}{$\begin{array}{c}\text { アマゾン } \\
\text { n=298 }\end{array}$} & \multicolumn{2}{|c|}{$\begin{array}{c}\text { 楽天市場 } \\
\text { n=297 }\end{array}$} & \multicolumn{2}{|c|}{$\begin{array}{c}\text { ヤフーショッピング } \\
\mathrm{n}=281\end{array}$} & \multicolumn{2}{|c|}{$\begin{array}{l}\text { ロハコ } \\
\mathrm{n}=206\end{array}$} & \multicolumn{2}{|c|}{$\begin{array}{c}\text { キューテン } \\
\mathrm{n}=209\end{array}$} \\
\hline & 平均值 & 標準偏差 & 平均値 & 標準偏差 & 平均值 & 標準偏差 & 平均值 & 標準偏差 & 平均值 & 標準偏差 \\
\hline 履歴がしっかり残される & 5.56 & 1.22 & 5.67 & 1.12 & 5.34 & 1.24 & 5.23 & 1.23 & 4.83 & 1.47 \\
\hline 商品比較が楽にできる & 4.78 & 1.33 & 4.62 & 1.40 & 4.75 & 1.23 & 4.69 & 1.28 & 4.25 & 1.40 \\
\hline 商品の絞り込みがしっかりできる & 4.71 & 1.38 & 4.79 & 1.34 & 4.87 & 1.16 & 4.88 & 1.33 & 4.35 & 1.46 \\
\hline 手間がかからず良い商品が手に入る & 4.83 & 1.34 & 4.87 & 1.28 & 4.81 & 1.16 & 4.95 & 1.25 & 4.64 & 1.35 \\
\hline 商品に間違いがない & 4.43 & 1.31 & 4.70 & 1.16 & 4.69 & 1.11 & 5.06 & 1.23 & 3.95 & 1.31 \\
\hline 魅力的な商品に出会える & 4.72 & 1.16 & 4.83 & 1.10 & 4.74 & 1.13 & 4.83 & 1.29 & 4.76 & 1.36 \\
\hline ギャンブル感がある & 3.05 & 1.50 & 2.86 & 1.36 & 2.93 & 1.40 & 2.96 & 1.62 & 3.68 & 1.63 \\
\hline $\begin{array}{l}\text { タイムセールやアウトレットセールが } \\
\text { 頻繁にある }\end{array}$ & 4.54 & 1.37 & 5.02 & 1.19 & 4.61 & 1.22 & 4.79 & 1.32 & 5.31 & 1.54 \\
\hline クーポンがよく提供される & 3.57 & 1.54 & 5.10 & 1.27 & 4.73 & 1.31 & 4.45 & 1.48 & 5.11 & 1.51 \\
\hline ポイントがしっかりたまる & 3.78 & 1.66 & 5.84 & 1.21 & 5.24 & 1.29 & 4.81 & 1.38 & 4.09 & 1.45 \\
\hline 決済が安心して行われる & 5.35 & 1.30 & 5.60 & 1.08 & 5.49 & 1.19 & 5.41 & 1.35 & 4.82 & 1.43 \\
\hline 配達がきちんと行われる & 5.36 & 1.33 & 5.52 & 1.14 & 5.43 & 1.15 & 5.47 & 1.33 & 4.50 & 1.48 \\
\hline
\end{tabular}

成したものである（表 2 参照）。次に，直近の購買経験 に基づく評価を得るため, 模擬的な購買課題を課した上 で, 買物のスマートさおよび買物の楽しさ, ロイヤルティ の尺度への回答が求められた。買物のスマートさと買物 の楽しさは，Ishibuchi（2019）における感情経験におけ る尺度を参考にしながら，グループ・インタビューの知 見を踏まえて設定した（表 3 参照）。ロイヤルティは， 認知的ロイヤルティ, 態度的（感情的）ロイヤルティ, 意図 (意欲) 的ロイヤルティ, そして行動的ロイヤルティ の 4 段階で捉え（Oliver, 1999），Takahashi（2009）を参 考に設定した（表 3 参照）。また，ここでの尺度は，い ずれも 7 件法（1. 全くあてはまらない〜 7. 非常にあて はまる）であった。

各モバイルアプリの保有者数は，1,291 サンプルの内,
アマゾン 905 人 $(70.1 \%)$, 楽天市場 1,130 人 $(87.5 \%)$, ヤフーショッピング 747 人 $(57.9 \%)$ ， ロハコ 365 人 $(28.3 \%)$ ，キューテン 331 人 $(25.6 \%)$ であった。割付 を行っているため, ロハコやキューテンも一定の保有者 がいるが, リーダー型アプリを想定したモバイルアプリ はそれぞれ半数を超えている。各モバイルアプリの割り 当て人数, 利用および購買頻度の割合を表 1 に示してい る。

表 2 では, モバイルアプリの特徴や機能・サービスに 関わる項目について，モバイルアプリ毎の平均值，標準 偏差を示してある。回答者は, 割り当てられた当該モバ イルアプリのユーザーであるため，比較的高い值となっ ている。リーダー型モバイルアプリを想定した衣食住全 般に関わる商品を広く取り扱う国内の主要 3 つの $\mathrm{EC} の$ 


\begin{tabular}{|c|c|c|c|c|c|c|}
\hline 変数名 & 項目 & 平均値 & 標準偏差 & $\begin{array}{c}\text { 項目合計 } \\
\text { 平均值 }\end{array}$ & $\begin{array}{l}\text { 項目合計 } \\
\text { 標準偏差 }\end{array}$ & $\begin{array}{c}\text { Cronbach } \\
a\end{array}$ \\
\hline \multirow{3}{*}{ 買物のスマートさ } & 軽快に操作できる & 5.04 & 1.26 & 4.92 & 1.15 & .874 \\
\hline & 時間が節約できる & 4.71 & 1.32 & & & \\
\hline & 効率的に買い物が出来る & 5.01 & 1.28 & & & \\
\hline \multirow[t]{2}{*}{ 買物の楽しさ } & 楽しい & 4.91 & 1.22 & 4.87 & 1.19 & .953 \\
\hline & ワクワクする & 4.84 & 1.22 & & & \\
\hline \multirow[t]{3}{*}{ 認知的ロイヤルティ } & $\begin{array}{l}\text { 私は、商品を購入する上で、他の EC アプリと比較してこの EC アプリを優れたサー } \\
\text { ビスであると思う }\end{array}$ & 4.77 & 1.24 & 4.81 & 1.15 & .935 \\
\hline & 私は、商品を購入する上で、この EC アプリを価值あるサービスであると思う & 4.88 & 1.20 & & & \\
\hline & 私は、商品を購入する上で、この EC アプリを品質の高いサービスであると思う & 4.80 & 1.23 & & & \\
\hline \multirow[t]{4}{*}{ 態度的ロイヤルティ } & 私は、商品を購入する上で、この EC アプリをひいきにしている（愛顧している） & 4.61 & 1.49 & 4.70 & 1.27 & .919 \\
\hline & 私は、商品を購入する上で、この EC アプリをいちばんに選ぶ & 4.32 & 1.64 & & & \\
\hline & 私は、商品を購入する上で、この EC アプリが好きである & 4.89 & 1.27 & & & \\
\hline & 私は、商品を購入する上で、この EC アプリを良いと思う & 4.97 & 1.21 & & & \\
\hline 行動意図的 & 私は、次回購入する際も、この EC アプリの利用を検討したい & 5.03 & 1.32 & 4.72 & 1.31 & .920 \\
\hline \multirow[t]{3}{*}{ ロイヤルティ } & 私は、次回、EC アプリを利用する場合、この EC アプリを第一候補にすると思う & 4.38 & 1.66 & & & \\
\hline & 私は、これからも、この ECアプリで購入し続けたい & 4.95 & 1.38 & & & \\
\hline & 私は、これから 1 年間に、今までよりこの EC アプリを頻繁に利用したい & 4.52 & 1.44 & & & \\
\hline $\begin{array}{l}\text { 行動的ロイヤルティ } \\
\text { (反復性 \& 偏向性) }\end{array}$ & - & - & - & 3.91 & 1.43 & .834 \\
\hline \multirow{2}{*}{$\begin{array}{l}\text { 行動的ロイヤルティ } \\
\text { (反復性) }\end{array}$} & 私は、この EC アプリを継続して何度も利用してきた & 3.14 & 1.82 & 4.67 & 1.62 & .936 \\
\hline & 私は、この EC アプリで継続して何度も購買してきた & 3.14 & 1.83 & & & \\
\hline \multirow{2}{*}{$\begin{array}{l}\text { 行動的ロイヤルティ } \\
\text { (偏向性) }\end{array}$} & 私は、ECアプリを利用する場合、この EC アプリのみを利用してきた & 4.76 & 1.62 & 3.14 & 1.77 & .927 \\
\hline & 私は、ECアプリを介して購買する場合、この EC アプリのみで購買してきた & 4.59 & 1.73 & & & \\
\hline
\end{tabular}

中で，楽天市場ではポイントが溜まるという点や，クー ポンやタイムセールなどの割引プロモーションに関わる 項目の值が比較的高いが，反対にアマゾンは低いことが 分かる。そのため, リーダー型モバイルアプリ内でも少 なからずその特徴が異なっている。先ほどの表 1 におい て, 楽天において使用頻度の高い消費者の購買頻度が低 い理由として，品定めをした上で割引プロモーションが 展開される夕イミングで慎重に購入を行っているという 可能性も考えられる。

また,「製品カテゴリーの総合性」と「機能の統合性」 が低いと位置づけられるモバイルアプリについて，まず, 市場特化型モバイルアプリを想定したロハコは, リーダー 型モバイルアプリと同様に平均的であるが, 商品に関わ る項目（商品に間違いがないなど）の值が比較的高くなっ ている。特定市場を対象に個々の商品の質に注力すると いう差別化が行われている可能性がある。続いて，機能 特化型モバイルアプリを想定したキューテンは, タイム セールやアウトレットセールが頻繁にある，クーポンが よく提供される，ギャンブル感があるという項目の值が 高くなっており, 割引プロモーションといった機能やギャ
ンブル感などの高揚感の演出に重点を置いたモバイルア プリであると言えるだろう。

続いて, 買物のスマートさや買物の楽しさ, そして, 4 つのロイヤルティにおけるすべての測定項目について, 天井効果と床効果がみられないことや正規性が確認され た。信頼性係数を基準に, 各項目の得点の合計を質問項 目数で除した值（項目合計平均值）を用いた。表 3 にお いて, 各項目の平均值, 標準偏差, 項目合計平均值と標 準偏差, クロンバック $\alpha$ の值を示してある。行動的ロイ ヤルティは，他と比べて信頼性係数が低くなっている $(\alpha=.834)$ 。複数のモバイルアプリの利用や使い分けなど が考えられるため, 下位の構成要素として，行動的口イ ヤルティ（反復性）と行動的ロイヤルティ（偏向性）に ついても取りあげている6)。また，いずれの行動的ロイ ヤルティでも, これまでの利用経験（調査時点までの行 動的ロイヤルティ）について確認する形となっている。

表 4 では, 買物のスマートさ, 買物の楽しさ, モバイ ルアプリに対するロイヤルティの各変数間の相関係数を 示している。買物のスマートさと買物の楽しさの相関係 数は比較的高い值となっているが, VIF の值は 5 を下回っ 


\begin{tabular}{|c|c|c|c|c|c|c|c|c|}
\hline \multirow[b]{2}{*}{$\mathrm{n}=1,291$} & \multicolumn{8}{|c|}{ 相関係数 } \\
\hline & $\begin{array}{c}\text { 買物の } \\
\text { スマートさ }\end{array}$ & $\begin{array}{l}\text { 買物の } \\
\text { 楽しさ }\end{array}$ & $\begin{array}{c}\text { 認知的 } \\
\text { ロイヤルティ }\end{array}$ & $\begin{array}{c}\text { 態度的 } \\
\text { ロイヤルティ }\end{array}$ & $\begin{array}{l}\text { 行動意図的 } \\
\text { ロイヤルティ }\end{array}$ & $\begin{array}{c}\text { 行動的 } \\
\text { ロイヤルティ } \\
\text { (反復性 \& 偏向性) }\end{array}$ & $\begin{array}{c}\text { 行動的 } \\
\text { ロイヤルティ } \\
\text { (反復性) }\end{array}$ & $\begin{array}{c}\text { 行動的 } \\
\text { ロイヤルティ } \\
\text { (偏向性) }\end{array}$ \\
\hline 買物のスマートさ & 1 & - & - & - & - & - & - & - \\
\hline 買物の楽しさ & $.670^{* *}$ & 1 & - & - & - & - & - & - \\
\hline 認知的ロイヤルティ & $.652^{* *}$ & $.615^{* *}$ & 1 & - & - & - & - & - \\
\hline 態度的ロイヤルティ & $.597^{* *}$ & $.585^{* *}$ & $.840^{* *}$ & 1 & - & - & - & - \\
\hline 行動意図的ロイヤルティ & $.558^{* *}$ & $.546^{* *}$ & $.774^{* *}$ & $.927^{* *}$ & 1 & - & - & - \\
\hline $\begin{array}{l}\text { 行動的ロイヤルティ } \\
\text { (反復性 \& 偏向性) }\end{array}$ & $.336^{* *}$ & $.332^{* *}$ & $.494^{* *}$ & $.699^{* *}$ & $.721^{* *}$ & 1 & - & - \\
\hline 行動的ロイヤルティ（反復性） & $.415^{* *}$ & $.397^{* *}$ & $.569^{* *}$ & $.735^{* *}$ & $.754^{* *}$ & $.830^{* *}$ & 1 & - \\
\hline 行動的ロイヤルティ（偏向性） & $.165^{* *}$ & $.174^{* *}$ & $.280^{* *}$ & $.459^{* *}$ & $.478^{* *}$ & $.860^{* *}$ & $.429^{* *}$ & 1 \\
\hline
\end{tabular}

$* * p<.01$

\begin{tabular}{|c|c|c|c|c|c|c|c|c|c|c|c|c|c|c|c|c|c|c|c|c|c|c|c|c|}
\hline \multirow[t]{2}{*}{ 変数名 } & \multicolumn{4}{|c|}{$\begin{array}{c}\text { 認知的 } \\
\text { ロイヤルティ }\end{array}$} & \multicolumn{4}{|c|}{$\begin{array}{c}\text { 態度的 } \\
\text { ロイヤルティ }\end{array}$} & \multicolumn{4}{|c|}{$\begin{array}{l}\text { 行動意図的 } \\
\text { ロイヤルティ }\end{array}$} & \multicolumn{4}{|c|}{$\begin{array}{c}\text { 行動的 } \\
\text { ロイヤルティ } \\
\text { (反復性 \& 偏向性) }\end{array}$} & \multicolumn{3}{|c|}{$\begin{array}{c}\text { 行動的 } \\
\text { ロイヤルティ } \\
\text { (反復性) }\end{array}$} & \multicolumn{5}{|c|}{$\begin{array}{c}\text { 行動的 } \\
\text { ロイヤルティ } \\
\text { (偏向性) }\end{array}$} \\
\hline & step1 & & step2 & & step1 & & step2 & & step1 & & step2 & & step1 & & step2 & & step1 & & step2 & & step1 & & step2 & \\
\hline リーダー型アプリダミー & .061 & * & .061 & ** & .091 & ** & .093 & *** & .101 & ** & .103 & ** & .173 & ** & .176 & ** & .139 & $* *$ & .140 & ** & .153 & ** & .156 & ** \\
\hline 買物のスマートさ & & & .429 & ** & & & .363 & $* *$ & & & .338 & ** & & & .188 & ** & & & .255 & $* *$ & & & .071 & + \\
\hline 買物の楽しさ & & & .330 & ** & & & .346 & ** & & & .324 & ** & & & .213 & ** & & & .231 & ** & & & .133 & ** \\
\hline$R^{2}$ & .004 & * & .487 & ** & .008 & ** & .427 & *** & .010 & ** & .376 & ** & .030 & *** & .164 & ** & .019 & $* *$ & .217 & ** & .023 & ** & .059 & *** \\
\hline
\end{tabular}

$* * \mathrm{p}<.01, * \mathrm{p}<.05,+\mathrm{p}<.10$

ており, 多重共線性の問題は回避されている。

モバイルアプリにおける買物のスマートさと買物の楽 しさがモバイルアプリに対するロイヤルティに与える影 響を検討するため, 買物のスマートさと買物の楽しさを 独立変数, それぞれのロイヤルティを従属変数とした階 層的重回帰分析（強制投入法）を行った（表 5 参照）。 分析は，以下の 2 つのステップで行った。まず，図 3 の モバイルアプリの競争類型における影響をみるため, 「リーダー型モバイルアプリ」と想定したアマゾン，楽 天，ヤフーショッピングを 1 ，その対比として想定した 「市場特化型モバイルアプリ」（ロハコ）および「機能特 化型モバイルアプリ」(キューテン) を０とするリーダー 型モバイルアプリダミー変数をコントロール変数として 用いたステップ1である。そして，買物のスマートさと 買物の楽しさの各ロイヤルティへの影響をみるステップ 2 である7)。

リーダー型モバイルアプリダミーの各ロイヤルティへ
の影響をみたステップ 1 の分析結果として, R2 值は低い ものの, $5 \%$ 水準で有意であった認知的ロイヤルティ以 外, 他のロイヤルティは全て $1 \%$ 水準で有意であった。 そのため, それぞれのロイヤルティの変動の説明力は低 いが，リーダー型モバイルアプリであると，モバイルア プリに対するそれぞれのロイヤルティは高い。この説明 力の低さについては, 以下のことなどが考えられる。リー ダー型モバイルアプリは，基本的には「マス・マーケッ 卜」を対象として標準化が志向されるため, ロイヤルティ には影響を及ぼしにくいものと考えられることや, グルー プ・インタビューの知見や表 2 の結果から, リーダー型 モバイルアプリ間でも違いがあり, 消費者は購買課題や 購買目的などにより使い分けている可能性があることな どであろう。

次に, ステップ 2 の分析結果として，買物のスマート さと買物の楽しさを説明変数とした際のロイヤルティへ の影響に関して, 各モデルの R2 值は, 表 5 の通りであ 
り、リーダー型モバイルアプリダミーを統制しても全て $1 \%$ 水準で有意であった。行動的ロイヤルティ（偏向性） 以外は，それぞれのロイヤルティにおいてステップ1よ りもステップ 2 の R2 值の方が大幅に高くなっており， ロイヤルティの変動を説明する要因として, 買物のスマー トさと買物の楽しさが説明力を有していることを示して いる。また，他のロイヤルティに比べて，行動的ロイヤ ルティ（反復性\&偏向性，反復性，偏向性）に関しては, いずれも R2 值が低くなっているものの, 買物のスマー 卜さや買物の楽しさは, 総じて, どちらもモバイルアプ リに対するロイヤルティに正の影響を及ぼしていた。買 物のスマートさと買物の楽しさが各ロイヤルティに与え る影響を示す標準偏回帰係数（標準化係数）は，表 5 の 通りであるが，買物のスマートさが行動的ロイヤルティ （偏向性）に与える影響は $10 \%$ 水準で有意な傾向であっ た以外は，いずれも $1 \%$ 水準で有意であった。

このように，買物のスマートさと買物の楽しさは，そ れぞれが各種のロイヤルテイに影響を及ぼしている。こ れらの結果から，モバイルアプリにおける買物のスマー 卜さや，買物の楽しさを消費者に対して提供することが 重要であることがわかるだろう。

\section{V. おわりに}

本稿では, デジタル変革のなかで, 主に小売業におけ る競争の場としてのモバイルアプリを取りあげ，その裏 側で展開される流通ビジネスモデルの現状と表側で展開 されるモバイルアプリの競争類型，加えて，消費者目線 からモバイルアプリに求められる機能やモバイルアプリ 間の競争について考察を行った。その上で，消費者のモ バイルアプリの利用実態と認識について探索的に行われ た調查結果の一部を示した。

グループ・インタビュー調查からは，モバイルアプリ の利用抢よび利用継続（ロイヤルティ）に関わる重要な 要素が確認されたほか,「製品カテゴリーの総合性」や 「機能の統合性」に対する消費者の認識も明らかとなっ た。「買物のスマートさ」と「買物の楽しさ」についても その内容が確認されたほか,「製品カテゴリーの総合性」
および「機能の統合性」の高さと必ずしも対応していな いことや，モバイルアプリの利用や利用継続（ロイヤル ティ）に関わる重要な要素にもあげられることなどが確 認された。

質問調査の結果からは，消費者が認識するモバイルア プリの特徴と，モバイルアプリに扔ける買物のスマート さや買物の楽しさがロイヤルティに影響を及ぼしている ことが明らかとなった。その際,リーダー型モバイルア プリは，ロイヤルティに対する影響力が低かったが，リー ダー型モバイルアプリ間でも違いがあり，また消費者が モバイルアプリを使い分けている可能性があることなど が考えられる。こうした調查結果からは，裏側のビジネ スモデルを反映した機能の統合体としてのモバイルアプ リに対して，表側では，スマートさと楽しさという観点 から要約的に捉えた機能の統合体が認識されていること が確認できた。

一方で, 調查における課題も残されている。今回の 2 つの探索的な調査では, どちらも特定の条件をもつセグ メントを対象に限定したものであるために, 他の条件や 異なるセグメントについても調查する必要がある。加え て, 買物のスマートさ, 買物の楽しさ, ロイヤルティに 関して, 構成概念の精查に加え, 測定尺度の精緻化を行 う必要がある。こうした構成概念は，消費者の情報処理 規定要因である MAO（動機づけ, 能力, 機会）により 大きな影響を受けることから，これらの規定要因との関 係を詳細に検討していく必要もあるだろう。

本稿に扔けるインプリケーションは以下の 3 つであ る。(1)モバイルアプリを展開する小売業者は，買物のス マートさと買物の楽しさを最大化するために，自らの流 通ビジネスモデルの発展と限界を踏まえながら，「製品力 テゴリーの総合性」と「機能の統合性」を設計すること が必要である。(2)リーダー型以外のモバイルアプリを展 開する事業者は, 上記に加えて, 市場を明確化し, 対象 顧客の求める特定機能を絞り, 適切性を高めたモバイル アプリに調整する必要がある。(3)既存の小売ビジネスを 展開する小売業者や消費者への直販を狙う製造業者など の事業者は，モバイルアプリの競争類型を考虑しながら 既存のプラットフォーマーに依拠した展開を行うか, 市 場ないし機能に特化した独自の価値を有するモバイルア 
プリの開発により, リーダー型モバイルアプリとの併用 を狙うことも一案であろう。

今後の研究の方向性として, 消費者による購買パター ンなどにみられる表側の行動面に加え，その裏側にある 消費者の心理面や生活行動とその背景にある生活意識な どについても理解していく必要がある。そのためには, 消費者との間に，いつでもどこでも繋がることが可能な モバイルアプリを通じて, 購買内外における経済的関係 および非経済的関係を構築し，その行動の捕捉と共にそ の心理面や生活体系の理解が求められる。

\section{謝辞}

本研究を進めるにあたり，法政大学名誉教授の矢作敏 行先生より貴重な文献とご助言を頂いた。また，慶応義 塾大学名誉教授の池尾恭一先生と同志社大学の高橋広行 先生より調査に関するアドバイスを頂いた。さらに，査 読者からも適切なコメントを頂いた。ここに改めてお礼 申し上げる次第である。本研究は JSPS 科研費 $16 \mathrm{~K} 03950$ の助成を受けたものである。

\section{注}

1）この小売業態の識別には，土地制約の問題も論じられてい るが, 本稿ではこの点を割愛した。

2）但し，実店舗などオフラインにおける相対的経営資源によ り対応は異なるであろう。

3） EC アプリとゲームやマンガなどの EC 以外のモバイルアプ リを明確にするため，調査では ECアプリと表記していた が，本稿ではモバイルアプリと統一して表記している。

4）ロハコは, マーケットプレイスサービスを 2021 年 4 月で終 了させ，現在では主に直販となっている。

5）本稿では, 紙幅の制限もあり, 以下の調査結果に押いてエ ンゲージメントを取りあげないが，例えば，購買目的を有 しない長時間の閲覧や閲覧時の没入, 定期的な商品チェッ クなどのエンゲージメント行動およびその関連行動などが 確認された。

6）本稿では，ロイヤルティを特定のブランドに固執するといっ た偏向性を組み込んだ概念（Wada, 1984）であると再評価 した上で, 行動的ロイヤルティを特定のモバイルアプリを 対象にした(1)反復的利用，および，(2)偏向的な利用の 2 つ の要素から構成されると位置づけて調査を行っている。

7）買物のスマートさと買物の楽しさの交互作用の影響をみる ステップ 3 を行ったところ, 行動的ロイヤルティ（反復性 \&偏向性）と行動的ロイヤルティ（反復性）のみ $1 \%$ 水準 で有意であったが，ステップ 2 の $\mathrm{R} 2$ 值とほとんど変わり なく, 標準偏回帰係数 (標準化係数) もそれぞれ.063 と.087 と低かった。

\section{References}

Huré, E., Picot-Coupey, K., \& Ackermann, C.-L. (2017). Understanding omni-channel shopping value: A mixed-method study. Journal of Retailing and Consumer Services, 39, 314330.

Ishibuchi, J. (2019). Shopping behavior and emotion. Tokyo: Yuhikaku.（石淵順也（2019）。『買物行動と感情：「人」らし さの復権』有斐閣）(In Japanese)

Niikura, T. (2015a). Decomposing of distribution function into marketing issues. The Journal of Marketing and Distribution, 516,2-3. (新倉貴士 (2015a).「流通機能の分解から捉える マーケティング課題」『流通情報』516,2-3）(In Japanese)

Niikura, T. (2015b). Mobile apps and buying decision process. Keio Business Forum, 32(1), 35-50.（新倉貴士（2015b）。「モバイ ルアプリと購買意思決定プロセス」『慶応経営論集』32(1), 35-50) (In Japanese with English abstract)

Nishihara, A. (2020). Relationship marketing ni okeru customer engagement: Engagement gainen no seiri wo tyuushin toshite. In S. Yamamoto, Y. Kunieda, \& C. Morito (Eds.). Service and Consumer Behavior (pp. 61-83). Tokyo: Chikura. (西原彰宏 (2020).「リレーションシップマーケティングに おける顧客エンゲージメント：エンゲージメント概念の整 理を中心として」山本昭二・国枝よしみ・森藤ちひろ（編） 『サービスと消費者行動』pp. 61-83, 千倉書房) (In Japanese)

Oliver, R. L. (1999). “Whence consumer loyalty?” Journal of Marketing, 63, 33-44.

Shimaguchi, M. (1986). Strategy and management. Tokyo: Nikkei. (嶋口充輝（1986)。『統合マーケティング：豊饒時代の市場 志向経営』日本経済新聞社) (In Japanese)

Shimaguchi, M., \& Ishii, J. (1987). The modern marketing. Tokyo: Yuhikaku.（嶋口充輝・石井淳蔵（1987）。『現代マーケティ ング』有斐閣）(In Japanese)

Takahashi, H. (2009). Brand loyalty derived prototipicality and concreteness: Base on the central tendency formation motivations within consumer's category. Journal of Marketing \& Distribution, 12(2), 41-58.（高橋広行（2009）。「典型性と 具体性から導かれるブランド・ロイヤルティ：消費者のカ テゴリー中心形成要因の理論をベースに」『流通研究』12(2), 41-58) (In Japanese)

Tamura, M. (2001). Principles of distribution. Tokyo: Chikura. (田村 正紀 (2001)。『流通原理』千倉書房) (In Japanese)

Yahagi, T. (2016). Deconstruction of distribution functions. Revolution of Retailing, April, 26-29. (矢作敏行 (2016).「流 通機能の脱構築を進めよ」『販売革新』4月号, 26-29) (In Japanese)

Yahagi, T. (2020). The third commercial divide (6). The Hosei Journal of Business, 56(4), 65-82. (矢作敏行 (2020). 「新 · 商業社会論（6）一流通のデジタル破壊一」『経営志林』 56(4), 65-82) (In Japanese)

Wada, M. (1984). Brand loyalty management. Tokyo: Dobunkan. (和 田充夫 (1984).『ブランド・ロイヤルティ・マネジメント』 同文館出版）(In Japanese) 


\section{西原 彰宏（にしはら あきひろ）}

2007 年関西学院大学商学部卒業後, 2009 年関西学院大学大 学院商学研究科修士課程修了。2012 年同博士後期課程単位 取得満期退学後, 2013 年同博士 (商学) 取得, 亜細亜大学 経営学部専任講師を経て現職。専門はマーケティング・マ ネジメント，消費者行動論。

\section{新倉 貴士（にいくらたかし）}

1989 年明治大学商学部卒業後, 1991 年横浜国立大学大学院 経営学研究科修士課程修了。1995 年慶応義塾大学大学院経 営管理研究科博士課程単位取得満期退学後, 1998 年同博士 (経営学) 取得, 関西学院大学商学部教授を経て現職。専門 は消費者行動論。 